\title{
A estranheza de Flusser: entre arte, ciência e filosofia
}

\section{Marcos N. Beccari'}

Resumo: Este artigo põe em evidência a estranheza de Vilém Flusser enquanto horizonte prevalente de sua ficção filosófica. Com isso, busca-se apontar as potencialidades desse horizonte estranho para uma compreensão paradoxalmente mais clara e propositiva da ciência em sua interface com a arte e a filosofia, na medida em que a dimensão ficcional é explicitada.

Palavras-chave: Vilém Flusser. ficção filosófica. ceticismo. arte e ciência.

\section{Flusser's strangeness: between art, science and philosophy}

Abstract: This paper highlights Vilém Flusser's strangeness as the prevalent horizon of his philosophical fiction. The aim is to point out the potentialities of this strange horizon for a paradoxically clearer and more purposeful understanding of science in its interface with art and philosophy, as the fictional dimension is made explicit.

Keywords: Vilém Flusser. philosophical fiction. skepticism. art and science.

I Doutor em Educação pela USP. Vínculo institucional: Professor Adjunto do Setor de Artes, Comunicação e Design da Universidade Federal do Paraná, Rua General Carneiro, 460, Edifício Don Pedro I, $8^{\circ}$ andar, Curitiba-PR, 80060150. E-mail: marcosbeccari@ufpr.br. ORCID: http://orcid.org/0000-0002-2178-097X. Lattes iD: http://lattes.cnpq. br/1779138299755162. Curitiba, Brasil. 


\section{Introdução}

Estrangeiro (e estranho) é quem afirma seu próprio ser no mundo que o cerca. Assim, dá sentido ao mundo, e de certa maneira o domina. Mas o domina tragicamente: não se integra. O cedro é estrangeiro no meu parque. Eu sou estrangeiro na França. $\mathrm{O}$ homem é estrangeiro no mundo ${ }^{1}$.

Nascido em Praga em 12 de maio de $1920^{2}$, Vilém Flusser viveu sua infância e juventude sob a tênue paz do Tratado de Versalhes e no seio de uma família de intelectuais judeus - seu pai Gustav Flusser fora um notório professor universitário de matemática e física. Começa a estudar filosofia em 1938, na Karls-Universität, mas no ano seguinte, mediante a invasão nazista, Vilém decide fugir para Londres junto com Edith Barth, sua namorada desde a infância. Na fuga, porém, ele é detido na fronteira da Holanda por não ter visto inglês. Edith chega à capital inglesa e, não sem dificuldades, consegue forjar um visto para Flusser, apresentando-o como combatente que não teria sido aceito em decorrência da cegueira (verdadeira) de um dos olhos. Após Paris ter sido tomada, o casal teme que a Inglaterra fosse o próximo país a ser invadido, e decide cruzar o oceano para se refugiar no Brasil. Ao desembarcar, em 1940, no porto do Rio de Janeiro, Flusser recebe a notícia de que seu pai havia morrido no campo de Buchenwald. Os demais familiares (avós, mãe e irmã) morrem todos em Auschwitz, em 1942.

Vilém e Edith casam-se no Rio de Janeiro e logo fixam-se em São Paulo, onde teriam três filhos. Impedido de frequentar a universidade brasileira - as escolas tchecas não eram reconhecidas em São Paulo, o que o obrigaria a recomeçar toda a escolaridade desde o antigo primário -, Flusser passará mais de dez anos trabalhando na empresa do sogro, a IRB (Indústrias Radioeletrônicas do Brasil Ltda.), prosseguindo em paralelo com seus estudos autodidatas. Seu primeiro artigo é publicado em 1957, na Revista Brasileira de Filosofia. No início dos anos 1960, torna-se professor de filosofia na Escola de Arte Dramática (EAD), no Instituo Tecnológico de Aeronáutica (ITA) e na Fundação Armando Álvares Penteado (FAAP), instituição esta que ele ajudou a fundar. Em 1967, passa a lecionar filosofia

1 Flusser, Vilém. Natural:mente: vários acessos ao significado de natureza. São Paulo: Annablume, 2011, p. 52.

2 As informações biográficas aqui resumidas seguem os registros de Gustavo Bernardo Galvão Krause, biógrafo de Flusser e um de seus principais estudiosos. Para referenciá-lo, adoto a nomenclatura original de suas publicações, cuja autoria é designada ora como "Bernardo" ora como "Krause". 
da ciência na Universidade de São Paulo (USP), numa curta e conturbada passagem até 1970, quando seria exonerado³.

Apesar de sua ativa participação na vida intelectual de São Paulo - escrevendo regularmente ao Suplemento Literário do jornal O Estado de S. Paulo, e assinando depois a coluna diária "Ponto Zero" no jornal Folha de S. Paulo -, Flusser figurou como um estranho personagem desde o Golpe de 1964, à medida que evitava se posicionar à esquerda ou à direita - o que o tornava suspeito de ambos os lados. Ele já trouxera de Praga influências controversas: Marx e Wittgenstein - uma vez que seu pai fora, durante décadas, membro do partido socialista, até conhecer e se associar ao Círculo de Viena. A partir da leitura de Ortega y Gasset, Flusser descobre Nietzsche e mergulha em sua obra, reconhecendo ali suas próprias ideias sobre arte e linguagem ${ }^{4}$. Ou seja, para continuar trafegando entre correntes tão diversas, Flusser precisava manter-se intelectualmente "migrante", estrangeiro, nômade. Em 1972, não obstante, face ao regime instalado pelo Al-5, Flusser rescinde de suas aulas e decide retornar à Europa ${ }^{5}$.

Vilém e Edith passam pouco tempo na Itália, estabelecendo-se na França, onde o filósofo não é bem recebido 6 . Será ao longo dos anos 1980, moran-

3 Neste ano, a reforma universitária da USP reconduziu todos os professores de filosofia à FFLCH, e Flusser, que era professor da Escola Politécnica, não teve o contrato renovado por falta de comprovação de títulos acadêmicos. Gustavo Bernardo relata que "sua passagem pela USP foi bastante conflitiva. Flusser brigava com os colegas à esquerda e à direita, não apresentando a formação pós- graduada que dele se exigia; em lugar disso, entregava um currículo cada vez mais extenso e qualificado". Bernardo, Gustavo. A dúvida de Flusser: filosofia e literatura. São Paulo: Globo, 2002, p. 34.

4 Novamente conforme Bernardo (ibidem, p. 44), que também relata que, em carta a Paulo Leminsky, de 1964, Flusser revela seu entusiasmo com Albert Camus (p. 36); e que, em 1965, ele presencia uma aula de Foucault na USP e se alegra ao ouvir do pensador francês que "as filosofias de Heidegger e Wittgenstein são uma e a mesma filosofia". Sobre suas relações com Foucault, ver: Beccari, Marcos N. "Língua e discurso em Flusser e Foucault: um diálogo à espreita?". Intexto, n. 51, p. 362-378, Edição Especial Dossiê Flusser: 100 anos, 2020. Sobre a assimilação de Nietzsche por Flusser, ver o posfácio de Daniel B. Portugal no livro Língua e realidade, a ser relançado em 2021 pela É Realizações na coleção "Biblioteca Vilém Flusser".

5 Flusser assim o relata em sua autobiografia: “a juventude mudava rápida e radicalmente. Dividia-se em dois grupos que não são sequer opostos. [...] Minha tarefa de professor tinha cessado. Abandonei os jovens com coração pesado". Flusser, Vilém. Bodenlos: uma autobiografia filosófica. São Paulo: Annablume, 2007, p. 197, grifos no original. Posteriormente, em carta a Maria Lília Leão em 1983, lemos o seguinte testemunho: "Quanto aos fios que me prendem a pessoas, tenho duas experiências opostas. Todas as pessoas às quais fui ligado em Praga morreram. Todas. Os judeus nos campos, os tchecos na Resistência, os alemães em Stalingrado. As pessoas às quais fui ligado (e continuo ligado) em São Paulo, em sua maioria, continuam vivas. Embora, pois, Praga tenha sido mais 'misteriosa' que São Paulo, o nó górdio cortado foi macabramente mais fácil”. Flusser, Vilem. Ficções Filosóficas. São Paulo: Edusp, 1998, p. 11.

6 Conforme expõe o artista Fred Forest: "Brilhante, excessivo e extático, ele teve todas as qualidades necessárias para assustar os intelectuais de gabinete em seus ternos e gravatas. É por isso que 
do então na Alemanha, que Flusser adquire a fama de "filósofo das mídias" - o primeiro livro que publicou em alemão, Für eine Philosophie der Fotografie $^{7}$, foi traduzido em dez línguas e reeditado na Alemanha cinco vezes antes da morte de Flusser. $\mathrm{O}$ auge de sua carreira se exprime na publicação, em 1990, de Überflusser ("Sobre Flusser"), uma antologia organizada por Volker Rapsch que reúne ensaios de vários intelectuais europeus em comemoração ao septuagésimo aniversário do filósofo tcheco-brasileiro.

A estranheza, porém, permanecia: os otimistas o consideravam muito pessimista, enquanto os pessimistas não o entendiam, pois ele contestava o humanismo que amparava ambos. Enquanto Jean Baudrillard, por exemplo, lamentava que a realidade havia sido trocada por sua própria imagem - o que chamava de "simulacro" ${ }^{8}$-, Flusser não reconhecia diferença significativa entre imagem e realidade, motivo pelo qual também não aprovava a noção de "simulacro", que supõe uma noção duvidosa de "real". Mas, como observa Gustavo Bernardo", os primeiros leitores de Flusser "precisavam não entender as questões ambivalentes daquele desmancha-prazeres". Donde eu deduzo: liam-no por ser estranho.

Em novembro de 1991, poucos dias após ter debatido com Baudrillard em um congresso da Universität Duisburg-Essen, Flusser profere uma conferência no Instituto Goethe de Praga. Esta foi a primeira vez, após cinco décadas desde quando fugira dos nazistas, que Vilém retornara à sua cidade natal. Pensou em abordar o tema "o perigo dos nacionalismos", mas optou por "mudanças de paradigma". Diante do auditório lotado, Flusser empolgou-se a ponto de alternar, sem perceber, o tcheco, o alemão e o português. Por sua vez, a audiência atordoava-se com sua digressão frenética sobre o mundo digital e a cibernética: "mas só agora começamos a usar o telefone!"10.

ele foi marginalizado na França. Sua personalidade, seus paradoxos e seus gestos diferiam muito das afetações acadêmicas na terra de Descartes". In: Krause, Gustavo Bernardo; Mendes, Ricardo (orgs.). Vilém Flusser no Brasil. Rio de Janeiro: Relume Dumará, 2000, p. 48.

7 "Por uma Filosofia da Fotografia”. A primeira edição brasileira deste livro, em 1985, já se intitulava Filosofia da caixa preta. Ver: Flusser, Vilém. Filosofia da caixa preta. São Paulo: Hucitec, 1985.

8 Grosso modo, fenômeno em que o signo absorve o referente para se tornar mais real que o real em si: o simulacro converteria, de maneira irreversível, o real em sua própria sombra. Ver, a este respeito: Baudrillard, Jean. Simulacros e Simulação. Lisboa: Relógio d’Água, 1991.

9 Bernardo, Gustavo. A dúvida de Flusser, op. cit., p. 129.

10 Como relata Andreas Ströhl, então diretor do Instituto Goethe de Praga, Flusser "não se deixou 
No dia seguinte, antes de partirem, Vilém e Edith fizeram um piquenique no bosque em que se conheceram quando crianças. Partindo de volta à Alemanha, Edith, que estava dirigindo, bateu o carro contra um caminhão branco estacionado no meio da densa neblina. Ela quebrou a clavícula, e seu marido faleceu no ato. Flusser foi enterrado no Novo Cemitério Judeu de Praga, a poucos metros do túmulo de Franz Kafka, e sob uma inscrição em três idiomas: hebraico, tcheco e português ${ }^{11}$. Edith Flusser, que desde 1939 garantira os deslocamentos do marido pelo mundo, o acompanhou por toda a vida e, após o acidente nefasto, dedicou-se integralmente à organização e à publicação de sua obra. Ela foi enterrada ao seu lado em 2014.

\section{A fenomenologia do estranho}

[...] procurarei remover a neblina metafórica que encobre a neblina matinal, para tentar vê-la em sua concreticidade ${ }^{12}$.

Flusser foi certamente alguém estranho, talvez mais até do que estrangeiro $^{13}$. Não que ele o tenha deliberado, nem que lhe fosse cômodo ou incômodo de algum modo. A estranheza era o seu "estilo" (para não dizer "natureza") e, como tal, Ihe era inevitável. É ao menos o que se depreende da superfície de seus textos: ele não escrevia para não ser compreendido o que em si já é um tanto estranho à tradição filosófica -, mas justamente para ser o mais claro possível. Só que ele não conseguia não ser estranho. Flusser partia de ideias familiares para, gradualmente, desmontá-las e retraduzi-las. Como vimos, ademais, ele passou a vida toda sendo "estranhado"; não por acaso sua autobiografia intitulou-se Bodenlos: sem chão, apátrida, sem descendência.

Mas o que particularmente mais me estranha em Flusser é sua tão constante estima para com a fenomenologia de Husserl, este idealista que acredi-

desequilibrar nem pelos gritos de socorro dados pelo público fascinado, indefeso e pasmo, 'nós aqui chegamos no momento apenas ao nível do telefone'". Ströhl, Andreas. Vilém Flusser: Fenomenologie komunikace. Praga: Argo, 2016, p. 77, trad. minha.

11 De acordo com Eva Batlickova, "os textos em hebraico e em tcheco têm o mesmo significado. Trata-se da primeira parte do versículo de Oseias, 14:10: 'Quem é sábio compreenda isto, quem é inteligente reconheça-o!'. A frase em português, por sua vez, possui uma atmosfera completamente diferente: 'Não morremos conjugados. 'Nós' nunca morremos. Porque apenas eu e tu, a solidão é para a morte'”. Batlickova, Eva. O drama Saul: diálogo como um princípio descentralizador na obra de Vilém Flusser. Tese de Doutorado em Letras. São Paulo: FFLCH-USP, 2019, p. 62.

12 Flusser, Vilém. Natural:mente, op. cit., p. 139.

13 Acho curioso que, em alemão, "estrangeiro" e "estranho" são uma mesma palavra: fremd. 
tou ter desvendado nada menos que o fundamento de toda a filosofia. Esse importuno entrave à minha leitura de Flusser levou-me a assumir amiúde certa petulância como aquela de Anatol Rosenfeld, que, no famoso debate de 1964 em torno de Língua e realidade, considerava seus argumentos "esplêndidos, conquanto errados"14. Afinal, embora a fenomenologia tenha ganhado notável sobrevida ao longo do século XX (Heidegger, Sartre, Merleau-Ponty), muito do que marcou o pensamento francês a partir dos anos 1960 - em relação ao qual Flusser não estava alheio ${ }^{15}$ - provém da insatisfação para com a teoria fenomenológica, à guisa de três grandes vertentes: a linguística, a psicanálise e Nietzsche.

Sob o prisma nietzschiano-foucaultiano pelo qual eu me situo, o que há de inconveniente na fenomenologia é não apenas sua convicção de, pela suspensão dos juízos (epoché), ter-se acesso ao gesto fundador (intencionalidade) de todo conhecimento possível, mas antes a primazia assim subsumida do sujeito do conhecimento, princípio arraigado no pensamento ocidental desde Descartes. Como Foucault bem assinala em As palavras $e$ as coisas, a fenomenologia não fez mais que reativar o cogito cartesiano no registro do impensado, de modo que o "penso" não mais conduz à evidência do "existo", mas às condições kantianas da possibilidade de se pensar ${ }^{16}$. Por conseguinte, duvida-se da natureza, mas não do sujeito; duvida-se dos alicerces epistemológicos, mas não do domínio ontológico do impensado (o "ser" pós-kantiano). Em suma - e nisso se alinham Descartes, Kant e Husserl -, duvida-se para superar a dúvida.

Flusser, no entanto, não poderia deixar de fazer um uso estranho dessa dúvida - num ceticismo irônico, de acordo com Gustavo Bernardo ${ }^{17}$, ou numa fenomenologia especulativa, nos termos de Rachel Costa, para quem Flusser teria operado "uma espécie de atualização pós-estruturalista da fenomenologia de Husserl"18. Ainda que ele próprio talvez não o admitisse, Flusser duvidava do duvidar per se, sabendo da necessidade de

14 Ver, a este respeito: Bernardo, Gustavo. A dúvida de Flusser, op. cit., p. 149-154.

15 Ver, a este respeito: Beccari, Marcos N. "Língua e discurso em Flusser e Foucault: um diálogo à espreita?", op. cit., p. 362-378.

16 Ver: Foucault, Michel. As palavras e as coisas: uma arqueologia das ciências humanas. São Paulo: Martins Fontes, 2000, p. 448-449.

17 Bernardo, Gustavo. A dúvida de Flusser, op. cit., p. 57.

18 Costa, Rachel Cecília de Oliveira. "Ficção como fruto da falta de fundamento: a fenomenologia especulativa de Vilém Flusser". Viso: Cadernos de estética aplicada, v. XII, n. 23, p. 177-188, jul./ dez. 2018, p. 182. 
se suspender a própria suspensão do juízo caso se queira conservar, justamente, a dúvida. Dito de outro modo, "Flusser transforma a ausência de fundamento em modelo para construção de fundamento"19.

Equivoca-se, pois, a leitura que se atém ao nível literal do que Flusser chamava de "fenomenologia", assim como também se equivoca aquela que, como inicialmente eu o lia, não suspende o juízo prévio de enquadrá-lo na tradição fenomenológica. É preciso adotar uma leitura não literal e, ao mesmo tempo, não presumir qualquer coerência prévia - o estranho, afinal, reside precisamente entre o familiar e o contraditório. Somente assim pode fazer algum sentido a distinção que, em Natural:mente, Flusser estabelece entre metafísicos e fenomenologistas: como atitudes opostas de, respectivamente, buscar a profundidade e elogiar a superficialidade. Ora, uma asserção como "o pensamento profundo me parece ser mais superficial que o pensamento que procura captar a superfície das coisas"20 jamais seria endossada por Husserl, até porque se aplica muito bem como crítica à sua filosofia. Portanto, se a concepção flusseriana de "fenomenologia" mostra-se alheia a qualquer literalismo ou coerência, talvez seja em decorrência da estranheza que lhe era impossível de ser posta em suspenso.

\section{Quando o natural mente}

Caso se possa atenuar, ou pôr em suspenso, esse tipo de entrave, podemos tentar compreender como, "no esforço de confirmar ou refutar sua suspeita, o autor submetia as suas experiências com coisas naturais a testes sucessivos" $^{21}$. A suspeita é a de que, como insinua o título de seu livro, o natural "mente". Não que o não-natural possa falar a verdade, ou mesmo que exista algo não-natural, sequer uma natureza. A questão é que Flusser passa ao largo de dicotomias do tipo natureza-artifício ou verdade-mentira para privilegiar a ambivalência: é melhor consultar um mapa para se orientar na paisagem ou consultar a paisagem para se orientar no mapa? Há alguma diferença?

Em Natural:mente, Flusser desenha um anti-mapa para uma paisagem outra: um mapa em que as vacas aparecem como "máquinas eficientes para 
a transformação de erva em leite"22, e uma paisagem quase inacessível, dada a ausência de um lócus comum entre coisas como pássaros, chuva e a falsa primavera. Aqui, portanto, não é a natureza o que está em jogo, mas a condição traiçoeira dos mapas. É nesse sentido que o natural "mente": porque nunca houve nada de natural na natureza ou em qualquer outro lugar. O natural é o princípio ficcional dos mapas - tanto quanto o ideal de objetividade o é em relação às ciências e, sobretudo, à fenomenologia que as criticava ${ }^{23}$.

Termos tão amplos ameaçam se tornarem vazios e isentos de significado. Está possivelmente na hora de abandonarmos o termo "natureza" em favor dos termos mais modestos e mais significativos. Tal proposta é obviamente utópica porque o termo "natureza" está tão fundamentalmente enraizado nas nossas línguas e no nosso pensamento que continuará a atrapalhar nossa vivência e os nossos atos ${ }^{24}$.

Seria fácil, mediante asserções como essa, atribuir à Flusser a pecha de relativista. Mas ao indagar a falsa naturalidade dos mapas (teóricos, científicos, filosóficos etc.), Flusser não nega a realidade do mundo nem a dimensão política ou ética da ação humana. A questão é que os mapas são, a um só tempo, os limites e as condicionantes de toda realidade humana. $\mathrm{E}$ o anti-mapa de Flusser, por sua vez, toma a desorientação como bússola, obrigando-nos a dar um passo atrás para elaborarmos nossos próprios mapas. Porque é preciso orientar-se em todo caso, mas sem perder de vista a arbitrariedade das coordenadas. Não se trata de relativismo, apenas de desnaturalismo.

Desse ponto de vista, aliás, o relativista ainda estaria imerso na busca pelo que supostamente há por trás ou no fundo dos fenômenos, por mais que se negue uma explicação universal. Eu diria mesmo que a fenomenologia é a apoteose filosófica do relativismo. Bem diferente é o reconhecimento dos mapas enquanto ficções. Sendo a ficção, portanto, não uma imitação dissimuladora de realidade, mas antes a tessitura, senão do real, de seu desenrolar cartográfico. Nos estudos flusserianos, ademais, já não é novidade a prerrogativa acerca da condição ficcional de toda filosofia, bem como a

22 Ibidem, p. 53.

23 Afinal, nos termos de Foucault, a fenomenologia "jamais pôde conjurar o insidioso parentesco, a vizinhança ao mesmo tempo prometedora e ameaçante com as análises empíricas sobre o homem; [...] o projeto fenomenológico não cessa de se resolver numa descrição do vivido que, queira ou não, é empírica". Foucault, Michel. As palavras e as coisas, op. cit., p. 449.

24 Flusser, Vilém. Natural:mente, op. cit., p. 152-153. 
assunção de uma "ficção filosófica"25 - não no sentido de ficção da filosofia (o que seria análogo à ficção científica), mas de filosofia como ficção.

Embora Flusser tenha recebido tal epíteto de bom grado, certamente sabia que não havia nele qualquer ineditismo ou valor elevado. No artigo Da ficção $0^{26}$, escrito em 1966, Flusser lembra como, dos platônicos aos impressionistas, passando pelo cristianismo medieval, pelo renascimento, pelo barroco e pelo romantismo, a ficção explica a realidade. Na sequência, Flusser articula Husserl com Wittgenstein, tecendo um atordoante argumento para concluir que, apesar da contradição lógica, "realidade é ficção, e ficção é realidade" - sem admitir, porém, o caráter ficcional de suas premissas filosóficas. Não obstante, Flusser se rende à dicotomia: "Tudo isto é loucura. Tudo isto é fingimento. A nossa época se finge de louca. [...] De tanto fingirmos acreditar na ficção da vivência e da razão, acabamos perdendo a fé na realidade ${ }^{27}$.

Naquele momento, Flusser ainda não conseguia enxergar a ficção de seus próprios mapas. Reconhecimento este que vai depender de uma longa trajetória que, insistindo numa cartografia lógico-fenomenológica, mergulhará em uma contradição jamais resolvida. Nesse sentido, pois, Flusser mantinha-se refém da ficção, a começar pela de si mesmo: sua estranheza, suas mentiras, suas omissões ${ }^{28}$. Mas, ao mesmo tempo, talvez desconfiasse de que, afinal, as ficções sejam realidade (mais do que o inverso). Pois, como insistia Juan José Saer, "[...] ao dar o salto em direção ao inverificável, a ficção multiplica ao infinito as possibilidades de tratamento. Não dá as

25 Um ano antes da morte de Flusser, Abraham Moles, professor da famosa escola de design Hochschule für Gestaltung d'Ulm, cunhou o termo "ficção filosófica" em seu ensaio "Philosophiefiktion bei Vilém Flusser" ("A ficção filosófica nos escritos de Vilém Flusser"). Em 1998, a Edusp publicou Ficções Filosóficas (op. cit.), reunindo ensaios em que Flusser investiga como a ficção está na base do pensamento poético, histórico e científico. Ver, a este respeito: Moles, Abraham. "Philosophiefiktion bei Vilém Flusser". In: RAPSCH, Volker (Ed.). Überflusser: die Fest-schrift zum 70. von Vilém Flusser. Braunschweig: Stephan Bollmann Verlag, 1990, p. 53-61; Bernardo, Gustavo. "Ciência como ficção". In: Bernardo, Gustavo; Finger, Anke; Guldin, Rainer. Vilém Flusser: uma introdução. São Paulo: Annablume, 2008, p. 125-144.

26 Flusser, Vilém. Da ficção. O Diário de Ribeirão Preto, 26/08/1966. Disponível em: <http:// flusserbrasil.com/art2.html>. Acesso em março de 2020.

27 Ibidem, s. p.

28 Ver, a este respeito: Bernardo, Gustavo; Guldin, Rainer. O homem sem chão: A biografia de Vilém Flusser. São Paulo: Annablume, 2017. 
costas a uma suposta realidade objetiva: muito pelo contrário, mergulha em sua turbulência29."

Tanto como também o sabia Foucault, que não temia dizer-se ficcional:

Quanto ao problema da ficção, para mim é um problema muito importante; tenho consciência de que sempre escrevi somente ficções. Nem por isso quero dizer que isso esteja fora da verdade. Parece-me que há possibilidade de fazer trabalhar a ficção na verdade, de induzir efeitos de verdade com um discurso de ficção, e provocar, de algum modo, que o discurso de verdade suscite, fabrique alguma coisa que ainda não existe, que, então, "ficcione". "Ficciona-se" a história a partir de uma realidade política que a torna verdadeira, "ficiona-se" uma política que ainda não existe a partir de uma verdade histórica ${ }^{30}$.

É sob a égide desse nexo ficcional que Flusser poderá definir, em Natural:mente, algo como uma "verdadeira atitude científica pós-objetiva", que passa por "admitir que o nosso interesse pelas coisas, embora imposto sobre nós por elas, as torna coisas"31. Lógica que é bem similar à de Bruno Latour, ao afirmar, em 2008, que as "questões de fato agora claramente se tornaram questões de interesse" ${ }^{\prime 2}$. No original em inglês, Latour utiliza o termo matter, que pode significar tanto "questão" quanto "matéria". As expressões matters of fact e matters of concern brincam com tais acepções, uma vez que a matéria enquanto "questão de fato" remete a algo objetivo, ao passo que a matéria enquanto "questão de interesse" diz respeito a interesses igualmente objetivos. O raciocínio de Flusser segue na mesma trilha:

Enquanto o saber científico perambulava por regiões extra-humanas, nas quais o homem não está existencialmente interessado, era possível manter a ficção do conhecimento objetivo. Mas agora, quando o saber científico está penetrando regiões nas quais o homem está implicado (interessado), tal distinção fictícia entre o objeto conhecível e sujeito conhecedor se torna insustentável ${ }^{33}$.

29 Juan José. O conceito de ficção. Sopro: panfleto político cultural, agosto de 2009, p. 2. Disponível em: <http://www.culturaebarbarie.org/sopro/n15.pdf>. Acesso em abril de 2020.

30 Foucault, Michel. "As Relações de Poder Passam para o Interior dos Corpos". In: Ditos \& Escritos IX: Genealogia da ética, subjetividade e sexualidade. Rio de Janeiro: Forense Universitária, 2014, p. 43.

31 Flusser, Vilém. Natural:mente, op. cit., p. 158.

32 Latour, Bruno. "Um Prometeu cauteloso? Alguns passos rumo a uma filosofia do design (com especial atenção a Peter Slotedijk)". Trad. Daniel B. Portugal e Isabela Fraga. Agitprop: revista brasileira de design, v. 6, n. 58, jul./ago. 2014, s. p.

33 Flusser, Vilém. Natural:mente, op. cit., p. 155-156. 
Não por acaso Flusser gostava de citar o postulado de Wittgenstein segundo o qual as ciências nada descobrem, mas inventam. Isso nos leva a ponderar sobre uma questão que Flusser parece ter deixado em aberto: quais são, no campo científico, as consequências não das ficções, mas de admiti-las enquanto tais? Até que ponto, dito de outro modo, o natural "mente"? E o que implica "desmenti-lo"? No caso de Latour, não houve escapatória. Em meados da década de 1990, o físico polemista Alan Sokal publicou uma carta aberta convidando aqueles a quem ele denomina "construcionistas sociais", como Latour, a pularem do topo de um prédio de vinte andares, a título de pôr à prova o quanto a ciência é de fato socialmente construí$\mathrm{da}^{34}-\mathrm{ou}$, nos termos de Flusser, de fato ficcional (expressão que, como veremos, é um pleonasmo).

Claro que, para o cultivado leitor de Flusser ou Latour, esse tipo de provocação só revela uma completa incompreensão das ficções filosóficas. Mas, ao mesmo tempo, não foram poucos os filósofos e sociólogos que consideraram Latour um dos culpados da chamada "pós-verdade"35, como se ele tivesse reaberto a caixa de Pandora do criacionismo, do terraplanismo, da anti-vacina etc. Ora, isso só faria sentido, em primeiro lugar, se Latour fosse minimamente lido em tais comunidades, o que infelizmente é improvável. $E$, em segundo lugar, só faria sentido se Latour fosse um relativista - juízo de uma leitura apressada, tal como vimos em relação à Flusser. Em terceiro lugar, se o conhecimento científico é, por definição, falível e parcial, por que preocupar-se tanto com Latour (cujos questionamentos contribuem, nesse sentido, com a ciência) e não com aqueles que, de saída, preferem se fiar a um modelo alternativo?

Fato é que tais modelos alternativos são menos uma derivação das ideias de Latour do que uma validação delas. Pois assim como fizeram Flusser, Foucault e tantos outros, Latour apenas forneceu um "prognóstico" que hoje se comprova à medida que certo mapa "natural" passou a ser questionado e atacado, da mesma maneira que alguém só constata estar doente

34 Disponível em: <https://physics.nyu.edu/sokal/lingua_franca_v4/lingua_franca_v4.html>. Acesso em março de 2020. Ademais, Bruno Latour nunca falou em termos de "construção social", apenas argumentou que os fatos científicos deveriam ser vistos, antes de tudo, como um produto de procedimentos científicos.

35 Ver, a este respeito: Kofman, Ava. "Bruno Latour, the Post-Truth Philosopher, Mounts a Defense of Science". The New York Times Magazine, 25 out. 2018. Disponível em: <https://www. nytimes.com/2018/10/25/magazine/bruno-latour-post-truth-philosopher-science.html>. Acesso em março de 2020. 
a partir de seus sintomas. Logo, culpar Latour pela pós-verdade é como imputar ao médico ou à vacina a causa da doença - eis a paranoia de Sokal.

Ademais, não se pode ignorar que, desde $A$ Vida de Laboratório, seu primeiro livro, Latour sempre se manteve trabalhando junto a diversos cientistas (biólogos, geólogos, físicos etc.), chegando a contribuir diretamente em suas pesquisas. E desde Políticas da natureza até Down to Earth, Latour vem insistindo na necessidade de mobilizar a sociedade quanto às drásticas mudanças climáticas em curso - o que requer, segundo ele, maior clareza de como a ciência funciona (a partir de pessoas, investimentos, instituições etc.) em detrimento do mito de que ela esteja alheia ou "acima" da esfera política e cotidiana, como se os cientistas tivessem algum acesso privilegiado à realidade. Curiosamente, hoje a filosofia de Latour é mais lida e aplicada por cientistas do que por filósofos, razão pela qual muitos o consideram, na contramão da "pós-verdade", o filósofo do antropoceno - conceito gravado na virada do século para designar uma nova era em que a ação humana tornou-se o principal motor das transformações geológicas.

Os críticos de Latour poderiam delatar, de maneira novamente apressada, um percurso contraditório: um dos principais críticos do cientificismo agora emprega seus esforços em defesa da ciência. Mas o que escapa a tal juízo - ou o que nele se deseja fenomenologicamente suspender - é o fato de que Latour nunca questionou, por exemplo, a existência da gravidade ou a forma esférica da Terra. O que ele fez e continua a fazer é algo muito mais sutil: mapear as condições pelas quais o conhecimento científico torna-se propriamente conhecido - ou, pela mesma lógica, ignorado.

Com isso podemos finalmente responder à questão: em que medida o natural "mente"? Apenas na medida em que evitamos desmenti-lo. É nesse sentido que Flusser insistia em evidenciar a ficção do natural. Por mais estranho que possa parecer, desmentir o natural não implica negar a natureza, e sim devolver ao natural a sua condição ficcional - que, como vimos, não equivale a irreal. Nossos mapas são reais e, ao mesmo tempo, podem mentir. Estranhamente, portanto, há uma verdade que se revela quando o natural mente: a de que essa mentira não tem nada de natural.

\section{Um ceticismo especular}

\footnotetext{
Mas tais fábulas não podem ser meras teias secretadas por pesadelos e sonhos. Devem recorrer às redes das ciências, que são os únicos órgãos dos quais dispomos atualmente para orientarmo-nos nas profundezas. Não é que tais fábulas devam ser "ficções científicas", isto é: científicas a serviço de pesadelos e sonhos. Devem ser
} 
"ciências fictícias", isto é: superações da objetividade científica a serviço de um conhecimento concretamente humano ${ }^{36}$.

O que há em comum entre Flusser e Latour é o ceticismo. Não se trata propriamente de uma questão epistemológica, pois os céticos indagam-se menos sobre os modos de conhecer do que se haveria, antes, algum conhecimento possível. Isso não implica duvidar do real; a dúvida cética dirige-se tão somente às condições de possibilidade do que se diz "verdadeiro". O que também não implica perguntar qual é a "verdade da verdade" - uma contradição por petição de princípio. O cético joga com as verdades sem as perscrutar (como na fenomenologia) nem as denegar (como no niilismo), atentando apenas a quais ficções são postas em jogo. Eis o horizonte cético: o que existe são jogos, relações de força; os jogos mapeiam o real, mas também são mapeáveis; e se tudo existe enquanto jogo/mapa, embaralham-se as fronteiras entre ficção e realidade.

Sob esse viés, contudo, o que dizer sobre o uso "desonesto" da ficção, como nas fakenews ou nos revisionismos do Holocausto? A ressalva é pertinente, mas os exemplos são ruins. Porque tais ficções ou se creem verdadeiras ou pressupõem o dogma niilista de que tudo é mentira - em todo caso, portanto, pautam-se numa certeza "factual", não ficcional. Mas a ressalva é pertinente na medida em que nos permite distinguir ceticismo de cinismo: reconhecer ceticamente a dimensão ficcional do real não implica camuflá-la, mas justamente explicitá-la, o que invalida as consequências cínicas presumidas na ressalva. Daí que Flusser defendia não apenas "que todo discurso fosse uma ficção, mas também que todo discurso precisaria explicitar a sua condição ficcional"37. Já o discurso nazista foi uma ficção que nunca se assumiu com tal (também por isso as suas consequências foram tão nefastas); na mesma toada, os revisionismos do Holocausto e, por extensão, o que hoje chamamos de fakenews investem no relativismo cínico de que, sendo tudo mentira, tudo pode ser verdade.

Em contrapartida, tomemos o adágio nietzscheano, que Flusser gostava de repetir, segundo o qual a arte é melhor do que a verdade. Entendendo arte como ficção assumida da verdade, e esta como um mapa já dado, a

36 Flusser, Vilém. Vampyroteuthis Infernalis. São Paulo/Coimbra: Annablume/Imprensa da Universidade de Coimbra, 2012, p. 131.

37 Bernardo, Gustavo. "Ciência como ficção", op. cit., p. 132. 
arte é melhor do que a verdade na medida em que explicita o caráter ficcional da realidade e de seus mapas ${ }^{38}$. Ao ler Nietzsche em alemão, Flusser sabia que, na sentença "Kunst mehr werth ist als die Wahrheit" ("A arte é mais valiosa que a verdade") ${ }^{39}$, o termo kunst deriva do verbo koennen, que significa "poder", no sentido de ser capaz ou saber fazer. Arte é, então, o produto da capacidade ou do poder de criar algo, ao passo que a verdade é algo que se supõe já verdadeiro (warh, "verdadeiro" + heit, "unidade") e que, portanto, não pode ser criado. Se na lógica platônica, como se sabe, a verdade é a correspondência entre o mundo das aparências e o mundo das ideias, para Flusser e para Nietzsche o mundo das ideias é nada, e Platão, um niilista; logo, a verdade só pode surgir da e pela arte, tornando-se obra ou então nada.

Não há verdade prévia à ficção. Mesmo a verdade científica só advém de hipótese e experimentação. Para realizar um experimento sobre o movimento, muitas vezes o físico precisa desconsiderar coisas como a força da gravidade e a resistência do ar. É como se tais coisas não existissem - mas o cientista sabe que existem -, e desse modo a ciência cria e depende de mapas ficcionais para designar os fenômenos. Nenhum problema nisso, pois nem poderia ser de outro modo. O problema é quando se passa a crer que os mapas espelham os fenômenos, o que equivale a um retorno husserliano às "coisas mesmas". Nesse ponto, já não se trata de consultar o mapa para se orientar no mundo ou o inverso, mas de trocar um pelo outro. É um pouco como a anedota, contada por Gombrich ${ }^{40}$, de uma senhora que visita o ateliê de Matisse e, diante de um quadro, comenta: "Mas o braço dessa mulher está comprido demais!". Ao que o artista responde: "Madame, a senhora está enganada. Isso não é uma mulher, é um quadro".

De um lado, não há problema em se emocionar assistindo a um filme, quando o que se vê são apenas feixes luminosos. De outro, Nietzsche já

38 Ou, conforme argumenta Nietzsche, a arte "tem a boa consciência a seu favor, opõe-se bem mais radicalmente do que a ciência ao ideal ascético". Nietzsche, Friedrich. Genealogia da moral: uma polêmica. São Paulo: Companhia das Letras, 2009, III, § 25. Sobre as considerações nietzscheanas sobre arte e ciência, ver: Beccari, Marcos N. "A ciência é ascética, não cética: considerações nietzschianas sobre arte e verdade". Revista Não Obstante, v. 2, n. 1, p. 6-14, ago./dez. 2017.

39 Frase localizada em um dos fragmentos póstumos da primavera de 1888 . Ver o fragmento \#21 do grupo 14 do ano de 1888 no arquivo completo de obras e cartas de Nietzsche: <http://www. nietzschesource.org/eKGWB/index>. Acesso em abril de 2020.

40 Gombrich, Ernst Hans. Arte e ilusão. São Paulo: Martins Fontes, 1995, p. 39. 
nos advertia: "receio que não nos livraremos de Deus, pois ainda cremos na gramática"41.

Bem diferente é a recorrência em Flusser da noção de speculum: não tanto como reflexo e espelhamento, mas antes como inversão formal que produz uma visada de contradição incessante ${ }^{42}$. No ensaio "Do espelho", de 1966, o filósofo argumenta que, embora toda a história do pensamento possa ser contada em termos de variantes especulares ${ }^{43}$, hoje já "não estamos mais tão interessados na face reflexiva do espelho. $O$ nosso interesse está na outra face, naquela que está coberta pelo nitrato de prata. Estamos invertendo espelhos" ${ }^{\prime 4}$. Ora, esse tipo de diagnóstico duvidoso, porquanto inverificável, era um estranho modo de Flusser demarcar o seu interesse em particular - qual seja, pelo lado "avesso" dos espelhos.

Por isso ele pensa as imagens técnicas, por exemplo, como o inverso da representação tradicional, portanto não como espelhos ou janelas do mundo, mas como "virtualidades concretizadas"45. Nesse sentido, as telas luminosas sobre as quais repousamos diariamente os nossos olhos são imagens técnicas não pelo que espelham ou representam, mas por possibilitarem um modo de ver e estar no mundo em rede que só se realiza por meio delas. Com efeito, partindo da premissa cética de que a "concretude" das coisas não é alheia ao modo como as vemos e interpretamos, Flusser sustenta que imagens técnicas explicitam esse processo ao serem vistas: tal como em Sodoma e Gomorra, elas concretizam o nosso olhar ${ }^{46}$.

41 Nietzsche, Friedrich. Crepúsculo dos ídolos. São Paulo: Companhia das Letras, 2006, III, § 5.

42 Vale acrescentar que, no léxico médico, o "espéculo" é um instrumento para manter aberto algum orifício do corpo humano, permitindo ao operador uma visão direta da área de interesse e a possibilidade de realizar intervenções, como a biópsia. Creio que Flusser também opera tal ferramenta, ao menos em seu estilo ensaístico: cada texto abre uma "brecha" lógica e a esgarça até o ponto de arrebentar.

43 Conforme levou a cabo Richard Rorty, em seu célebre A filosofia e o espelho da natureza. Para Foucault, no entanto, esse modo de correlação epistêmica pautado no espelhamento entre as coisas e suas representações se dissolve no umbral do classicismo à modernidade. Ver, a este respeito: Foucault, Michel. As palavras e as coisas, op. cit., p. 70-80.

44 Flusser, Vilem. Ficções Filosóficas, op. cit., 67.

45 Flusser, Vilém. O elogio da superficialidade: O universo das imagens técnicas. São Paulo: É Realizações, 2019, p. 29.

46 Ver, a este respeito: Beccari, Marcos N. "Gestualidades - ou como dançar em torno do concreto". In: Flusser, Vilém. Elogio da Superficialidade: o universo das imagens técnicas. São Paulo: É Realizações, 2019, p. 301-316 (Col. Biblioteca Vilém Flusser). 
A inevitável dificuldade desse tipo de "reflexão" talvez seja atenuada se voltarmos ao gesto ficcional de sua filosofia. Em Vampyrotheutis Infernalis ${ }^{47}$ que, para Abraham Moles, é a obra que melhor expressa a ficção filosófica de Flusser -, lemos uma fábula que faz uso ostensivo da taxonomia biológica e é acompanhada por quinze pranchas ilustradas pelo biólogo e artista plástico Louis Bec e carimbadas pelo fictício "Instituto Científico de Pesquisa Paranaturalista". Diante desse livro, qualquer biólogo certamente se constrangeria (assim como fenomenólogos dariam passos atrás perante a fenomenologia flusseriana). Mas, pelo simples fato de a fábula assumir-se como tal, não é o caso de pseudociência - trata-se, no lugar, de espelhamento:

[...] o Vampyroteuthis vai surgindo como nosso próprio espelho. Como antípoda nosso, no qual todos os nossos aspectos são invertidos. Pois contemplar tal espelho, a fim de reconhecer-se nele, e a fim de poder alterar-se graças a tal reconhecimento, é o propósito de toda fábula, inclusive desta ${ }^{48}$.

Esse tipo de espelhamento abrevia o que talvez seja um dos principais artifícios de Flusser: refletir sobre a reflexão como um aparato de espelhos retorcidos, tentando com isso captar o momento em que se dá a inversão especular. Mas o artifício é ficcional, vale insistir, pois a fábula comparece no lugar do fenômeno que se está a refletir para que este possa, assim, tomar forma e materialidade. No caso de Vampyrotheutis Infernalis, Flusser opera uma reflexão até o ponto em que a estrutura biológica do molusco passe a espelhar a estrutura do mundo humano. Ao fim do livro, o autor relata o seu embaraço quando, no aquário de Banyuls, ele encarava fixamente o molusco, que igualmente o encarava atônito. Essa cena ecoa, como bem observou Gustavo Bernardo ${ }^{49}$, o conto "Axolotl" que Julio Cortázar escrevera em 1956, onde lemos a história de um escritor que visita diariamente um aquário público para observar um anfíbio ali exposto. O observador fica tão envolto com o que vê que, em determinado momento, descobre-se no corpo do axolotle, vendo seu ex-rosto do lado de fora do aquário.

Tal sorte de inversão especular também nos remete à metamorfose kafkiana ${ }^{50}$. No artigo "Esperando por Kafka", Flusser enaltece a estranheza de

\footnotetext{
47 O título desse livro é o nome científico de uma espécie rara do gênero octopodal (lulas e polvos) que vive em regiões abissais do oceano. Noutro momento, eu delineio a atualidade desta fábula filosófica de Flusser mediante o cenário político-midiático contemporâneo. Ver: Beccari, Marcos N. "O abismo através do espelho: a atualidade de Vampyroteuthis Infernalis de Vilém Flusser". Visualidades, v. 17, p. 14-25, 2019.

48 Flusser, Vilém. Vampyroteuthis Infernalis, op. cit., p. 134.

49 Bernardo, Gustavo. A dúvida de Flusser, op. cit., p. 133.

50 Ao menos em relação à figura popular que Gregor Samsa passou a representar no imaginário
} 
seu compatriota - um pouco à maneira como estou a fazer aqui -, argumentando que a "mensagem" kafkiana ainda não teria sido decifrada. Isso porque, segundo o filósofo, essa mensagem talvez seja o inverso do que se depreende dos textos: "Kafka é a existencialização de Nietzsche"51, pois a atmosfera repulsiva e absurda de seus textos funcionaria como um espelho do eterno retorno e, portanto, do imperativo nietzscheano de afirmação da vida. Noutros termos, a obsessão pela angústia e pelo tédio seria um modo estranho de Kafka transmutar todo "foi assim" em "assim eu quis".

Ora, novamente, mais provável é que tal leitura seja o estranho modo de Flusser afirmar a sua própria condição de estranho/estrangeiro. Uma condição que, justamente por não ter sido jamais escolhida, precisava ser escolhida dia após dia.

\title{
Considerações finais
}

\begin{abstract}
Migrar é situação criativa. Mas dolorosa. [...] Quando fui expulso de Praga (ou quando tomei a decisão corajosa de fugir) vivenciei o colapso do universo. É que confundi o meu íntimo com o espaço lá fora. Sofri as dores dos fios amputados. Mas depois, na Londres dos primeiros anos da guerra, e com a premonição do horror dos campos, comecei a me dar conta de que tais dores não eram as de operação cirúrgica, mas de parto. Dei-me conta de que os fios cortados me tinham alimentado, e que estava sendo projetado para a liberdade. Fui tomado pela vertigem da liberdade, a qual se manifesta pela inversão da pergunta "livre de quê" em "livre para fazer o quê". E assim somos todos os migrantes: seres tomados de vertigem ${ }^{52}$.
\end{abstract}

O que Flusser designa, no trecho acima, por "vertigem da liberdade" faz alusão direta, embora não referenciada, a uma conhecida passagem de Nietzsche: "Livre de quê? Que importa isso a Zaratustra! Mas teus olhos devem claramente dizer: livre para quê?" 53. A questão "livre de quê?" remete ao significado mais corriqueiro de liberdade, isto é, como o reverso de algo que aprisiona; já o segundo sentido, "livre para quê?", liga-se a um horizonte propositivo, e não a uma condicionante negativa.

moderno. Mas, como se sabe, em A metamorfose o termo "inseto monstruoso" aparece apenas na primeira frase; dali em diante, não há mais nenhuma menção à metáfora inicial.

51 Flusser, Vilém. Da religiosidade: a literatura e o senso de realidade. São Paulo: Escrituras, 2002, p. 81.

52 Flusser, Vilem. Ficções Filosóficas, op. cit., 14-15.

53 Nietzsche, Friedrich. Assim falou Zaratustra. São Paulo: Companhia das Letras, 2011, p. 61. 
Tal distinção esclarece o que eu dizia há pouco: se em Kafka pode haver algo de afirmativo, conforme a leitura de Flusser, é somente como reverso de um registro opressor, e não como "vertigem da liberdade" que Flusser associa à condição de migrante. Note-se, pois, como o espelho flusseriano é sempre um modo de refletir-se a si mesmo. Gustavo Bernardo, nesse sentido, chega a "reverter os atributos encontrados por Flusser na narrativa e no pensamento de Kafka, atribuindo-os ao texto e ao pensamento do próprio Flusser"54. Sob essa lógica, quando Flusser nos convida a esperar por Kafka, no fundo ele estaria nos convidando a esperar por ele mesmo. Isso explicaria o esquecimento de Flusser no Brasil: "pode ser menos uma típica ingratidão nacional do que, antes, decorrência do seu pensamento" ${ }^{55}$.

Concordo com a última asserção, mas não tanto com a mensagem "codificada" sob a sombra de Kafka; por mais que Flusser pudesse tê-lo em mente, aceitar seu "truque" implica confundir o mapa com a paisagem, ou o retrato com o retratado, mesmo que se trate de um autorretrato disfarçado. Pois o mapa flusseriano é o da estranheza cética, e não o da profecia gnóstica ${ }^{56}$, assumindo sempre a ficção enquanto gesto fundante. Claro que, no entanto, Flusser carregava nas tintas, conforme sintetiza Bernardo: "As frases muito diretas, os verbos predominantemente no presente do indicativo, a ausência de auxiliares, tudo parece caminhar para uma revelação que se basta a si mesma, quase para uma fala profética." ${ }^{57}$

Mas, apesar dessa maneira seca e "sincopada" que ele tinha de se expressar - o que salta aos olhos tanto nos textos quanto em suas aulas e conferên$\mathrm{Cias}^{58}$-, o seu modo de pensar é menos austero do que generoso, no sentido etimológico do termo: aquele que gera e engendra outros pensamentos.

54 Bernardo, Gustavo. A dúvida de Flusser, op. cit., p. 94.

55 Ibidem, p. 91.

56 Mesmo em Kafka, arrisco-me a dizer, não vejo a hermenêutica gnóstica que não raro é atribuída à sua obra. Vale lembrar, quanto a isso, um personagem da novela Na colônia penal: o "oficial" que carrega consigo uma pasta com supostas sentenças escritas pelo seu antigo comandante. Ocorre que tais sentenças são meros "rabiscos" ( gekritzel) - termo que, aliás, Kafka também adotava para descrever os seus próprios textos -, ou seja, nada nos autoriza a pressupor que há realmente algo escrito ali. Em minha leitura, pois, as sentenças decifradas pelo oficial provêm somente do seu desejo em sentenciar; por conseguinte, acredito que as supostas "mensagens" de Kafka nunca derivam de seus "rabiscos". Ver, a este respeito: Gagnebin, Jeanne Marie. "Escrituras do corpo". In: . Lembrar escrever esquecer. São Paulo: Ed. 34, 2006, p. 119-143.

57 Bernardo, Gustavo. A dúvida de Flusser, op. cit., p. 54.

58 Ver, por exemplo, a gravação do curso "Simulacro de Felicidade", ministrado no MASP em 1983, um dos raros registros de Flusser falando em português. Disponível em: <https://youtu.be/ Uy5mskJSmxA>. Acesso em abril de 2020. 
Outra coisa talvez elucide o seu estilo: em vez da escrita manual, Flusser preferia redigir diretamente na máquina de escrever. Precisava da resistência das teclas. Chegou a ganhar de presente um computador, mas nunca abdicara da mecânica datilográfica. Em The shape of things, Flusser indaga-se por que as máquinas de escrever fazem "clique", em vez de deslizarem suavemente como a caneta sobre o papel ${ }^{59}$. A partir de seu habitual nexo especulativo, o filósofo explica que máquinas em geral fazem "clique" porque gaguejam e funcionam aos saltos, do mesmo modo que tudo o que está vivo no mundo também gagueja e vive aos saltos.

A estranheza de Flusser, a despeito da fluidez que seu nome insinua, era o meio "truncado" pelo qual ele se permitia saltar entre os diversos campos, línguas e ficções. Saltar requer usar a resistência do chão; donde Flusser tomava como impulso enunciados firmes, nunca suaves. A opção pelo ensaio, por sua vez, é um meio de implicar-se no que se diz, comprometer-se, não tirar o corpo fora. Ele sabia que, sem a maestria necessária - isto é, sem saber jogar o jogo que os outros jogam -, um ensaio facilmente se passa por leviano e inoportuno. Mas Flusser assumia o risco como quem blefa inadvertidamente: "[...] começo a perder o meu assunto por ter-me identificado com ele. $\mathrm{E}$ simultaneamente começo a perder-me nele [...] $\mathrm{E}$ o estilo do meu ensaio passará a espelhar, a articular, a formular este meu empenho de corpo e alma." ${ }^{\prime 60}$

No léxico científico, "ensaio" designa o processo laboratorial empregado para identificar a atividade de um organismo ou substância. Sob esse prisma, Flusser operaria algo como um "meta-ensaio" - não somente porque seu objeto sempre é, no fundo, ele próprio (tanto o autor quanto o procedimento em $\mathrm{si}$ ), mas principalmente por evidenciar que a resultante do ensaio é desde o início ensaiada. É um pouco nessa toada que, em Contra o método, Paul Feyerabend tecia suas aporias: "Desvios ocasionados pela segunda lei da termodinâmica não são verificáveis, pois os instrumentos de medida estão sujeitos aos mesmos desvios das coisas que eles buscam medir." 61

\footnotetext{
59 Ver: Flusser, Vilém. The Shape of Things: A Philosophy of Design. London: Reaktion Books, 1999, p. 62-65.

60 Flusser, Vilem. Ficções Filosóficas, op. cit., 95.

61 Feyerabend, Paul. Contra o método. São Paulo: Editora UNESP, 2007, p. 350.
} 
Não é preciso ser anarquista como Feyerabend, ou quase fenomenólogo como Flusser, para saber que os mapas não espelham os fenômenos (antes o contrário). Basta ter em mente que todo espelho produz a inflexão das coordenadas refletidas. E isso, devo insistir, não invalida a ciência, mas apenas explicita a sua vocação em "produzir fatos", como Bruno Latour gosta de dizer. Para este filósofo francês, afinal, o que enfraquece a ciência é tão somente a visão "clássica" de ciência: a suposição de que os fatos falam por si mesmos e que, portanto, podem ser constatados da mesma maneira por todos. Admitir, por outro lado, que a ciência "produz fatos" - ainda que, de imediato, isso possa soar conspiratório - significa apenas reconhecer ceticamente que os fatos só se tornam propriamente factíveis à guisa de uma elaboração ficcional.

Voltando à Flusser, o espelhamento é o procedimento pelo qual ele refletia sobre como, para nos situarmos no mundo, precisamos mapeá-lo por meio das ficções. Ao operar, aos saltos, uma tal reflexão vertiginosa, seu intento era o de provocar e desdobrar novas reflexões. Por esse caminho, Flusser não apenas afirmava a estranheza; esta lhe servia também para firmar algum solo, posto que o migrante carecia de chão (bodenlos). Quanto a isso, aliás, arrisco-me a dizer que, se havia algo em comum entre Flusser e Kafka - além do fato de ambos terem sido judeus que nasceram e morreram em Praga - é a ausência de "fundo". Pois mesmo quando se crê, pelo velho ímpeto da decifração, ter encontrado alguma "mensagem" em seus textos, isso não prova que haja ali qualquer correspondência. Ambos nos mostram, afinal, que talvez não haja fundo no mundo. Não havendo fundo, resta-nos (a)fundar novos mapas indefinidamente.

Talvez por isso que ainda hoje escutamos ressoar o barulho derradeiro do carro chocando-se contra um espelho branco, vemos a neblina dissipar-se no chão de asfalto e, apesar de tudo, seguimos cultivando essa bela promessa de estranhamento. 